\title{
Identifikasi Telur Cacing pada Saluran Pencernaan Satwa Liar yang Dipelihara Masyarakat di Manokwari, Papua Barat
}

\section{Identification of Worm Eggs in the Digestive Tract of Wild Animals Maintained by the Community in Manokwari, West Papua}

\section{Dwi Nurhayati ${ }^{1)}$, Alnita Baaka ${ }^{1)^{*}}$, Freddy Pattiselanno ${ }^{2)}$}

${ }^{1)}$ Program Studi Kesehatan Hewan, Fakultas Peternakan, UNIPA, Manokwari, 98314, Indonesia

${ }^{2}$ Program Studi Budidaya Ternak, Fakultas Peternakan, UNIPA, Manokwari, 98314, Indonesia

Article history

Received: Nov 07, 2020;

Accepted: Jul 30, 2021

* Corresponding author:

E-mail:

a.baaka@unipa.ac.id

DOI:

10.46549/jipvet.v11i2.159

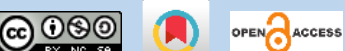

\begin{abstract}
One of the obstacles to captive wildlife by the community is the infestation of digestive tract worm eggs which have an impact on the health condition of these animals. This study was conducted to identify eggs of digestive tract worms in wild animals kept by the community in Manokwari, West Papua. Qualitative examination was carried out by native method and quantitative method by two methods, namely flotation and sedimentation. The results of observations of the feces samples of kept animals showed that in the samples of bird feces, namely parrots (10 tails), cockatoos (5 tails), mambruk ( 2 tails) and cassowaries (3 tails) no worm eggs were found. In the analysis of mammalian feces, it was found that the eggs of Nematode worms were found in 15 deer and Cestoda worms were found in 5 tree kangaroos. Identification of the findings based on Mohr, 1957, namely Taenia sp in kangaroos (Macropodidae), and, strongyle sp, Ascaris $\mathrm{sp}$ (embryo) in deer (Cervus timorensis). The results showed that the birds kept in Manokwari had not been infested with parasites, as evidenced by the absence of worm eggs. It is estimated that because all birds are caged, the possibility of direct infection is very small. Mammals that are kept infested with worm eggs are thought to be due to the maintenance system by displaying them in the yard. Identification of worm eggs in feces samples showed that there were 3 (three) types of worm eggs, namely Taenia sp in kangaroo (Macropodidae), Ascaris sp (embryo) and Strongyle sp in Timor deer (Cervus timorensis). The highest intensity of infestation came from the strongyle sp species (10 worm eggs and the lowest intensity was Ascaris sp (3 worm eggs). The level of gastrointestinal worm egg infestation in animals kept by the community in Manokwari is still relatively low.
\end{abstract}

Keywords: Gastrointestinal; Intensity; Wildlife; Worm parasites

\section{Abstrak}

Salah satu kendala penangkaran satwa liar oleh masyarakat adalah infestasi telur cacing saluran pencernaan yang berdampak terhadap kondisi kesehatan satwa tersebut. Penelitian ini dilakukan untuk mengidentifikasi telur cacing saluran pencernaan pada satwa liar yang dipelihara oleh masyarakat di Manokwari Papua Barat. Pemeriksaan kualitatif dilakukan dengan metode natif dan metode kantitatif dilakukan dengan dua metoda yaitu flotasi dan sedimentasi. Hasil pengamatan terhadap sampel feses satwa yang dipelihara menunjukkan bahwa pada sampel feses burung, yaitu Nuri (10 ekor), Kakatua (5 ekor), Mambruk (2 ekor) dan Kasuari (3 ekor) tidak ditemukan telur cacing. Pada hasil analisa feses mamalia ditemukan jenis telur cacing Nematoda pada 15 ekor rusa dan jenis telur cacing jenis Cestoda pada 5 ekor kangguru pohon. Identifikasi terhadap temuan berdasarkan Mohr, 1957 yaitu Taenia sp pada kangguru (Macropodidae), strongyl 
sp, dan Ascaris sp (berembrio) pada rusa (Cervus timorensis). Hasil penelitian menunjukkan bahwa burung yang dipelihara di Manokwari belum terinfestasi parasit, terbukti dengan tidak ditemukannya telur cacing. Diperkirakan karena semua burung dikandangkan maka kemungkinan terinfeksi secara langsung sangat kecil. Satwa Mamalia yang dipelihara terinfestasi telur cacing diduga karena system pemeliharaan dengan cara diumbar di halaman. Identifikasi telur cacing pada sampel feses menunjukkan ada 3 (tiga) jenis telur cacing, yaitu Taenia sp pada kangguru (Macropodidae), Ascaris sp (berembrio), dan strongyl sp pada rusa Timor (Cervus timorensis). Intensitas infestasi tertinggi berasal dari jenis strongyl sp (10 telur cacing) dan intensitas terendah adalah Ascaris sp (3 telur cacing). Tingkat infestasi telur cacing saluran pencernaan pada satwa yang dipelihara oleh masyarakat di Manokwari masih tergolong rendah.

Kata kunci: Gastrointestinal; Intensitas; Satwa liar; Parasit cacing

\section{PENDAHULUAN}

Penyakit kecacingan satwa liar yang telah didomestikasi masyarakat manokwari merupakan permasalahan yang harus mendapat perhatian serius dalam penangkarannya. Keberadaan endoparasit cacing pada masingmasing satwa liar yang ditangkarkan dapat menulari satwa liar lain yang ada dalam satu penangkaran. Ada 3 faktor utama penyebab penurunan populasi satwa liar, yaitu: kerusakan habitat akibat perambahan dan penebangan hutan, perburuan liar, dan penyakit yang belum banyak diketahui. Faktor penyakit khususnya cacing gastrointestinal (kecacingan) belum banyak mendapat perhatian, padahal dampaknya sangat besar terhadap kepunahan satwa liar (Andriansyah, 2008; Muryani, 2008).

Menurut Koibur et al. (2017), satwa yang umumnya dipelihara sebagai hewan kesenangan adalah berbagai jenis burung dengan tatalaksana pemeliharaan yang beragam mulai dari sederhana sampai dengan tahap yang lebih modern. Bentuk pemanfaatan satwa yang umum ditemukan di Papua adalah sebagai sumber protein hewani alternatif, hewan kesenangan (pets) (Pattiselanno, 2003; Pattiselanno, 2006) yang selain dipelihara, juga diperdagangkan. Hasil survey yang dilakukan oleh mahasiswa Program Diploma Kesehatan Hewan menunjukan bahwa dalam pengelolaan prasarana pemeliharaan seperti kandang, penyakit parasit perlu mendapat perhatian termasuk diantaranya adalah kecacingan. Satwa liar yang ditangkarkan harus memperhatikan kesehatan satwa dengan cara mencegah infestasi telur cacing parasit saluran pencernaan. Jika hal ini diabaikan maka sebagian zat makanan di dalam tubuh satwa dikonsumsi oleh cacing, sehingga menyebabkan kerusakan pada jaringan pencernaan (Hasan, 2012). Saluran pencernaan merupakan salah satu organ yang rentan terserang penyakit cacingan. Hewan ruminansia secara umum lebih rentan terjangkit penyakit cacingan. Kehadiran cacing dalam saluran pencernaan dapat menyebabkan kerusakan mukosa usus yang dapat menurunkan efisiensi penyerapan makanan. Keadaan tersebut menyebabkan pertumbuhan rusa menurun dan rentan terhadap penyakit lainnya yang dapat membahayakan kesehatannya (Larasati et al., 2016). Menurut Indradji et al. (2018), penularan cacing dapat terjadi melalui pakan dan minum yang tercemar oleh tinja. Terjadinya penularan penyakit adanya feses yang terinfestasi cacing. Infestasi adalah penyusupan organisme parasit ke dalam tubuh sehingga berkembang biak dalam jumlah yang besar dan merugikan kesehatan. Seperti dijelaskan Pratiwi (2010), organisme lain yang terdapat dalam feses tidak hanya cacing melainkan berupa telur cacing. Tinja yang mengandung telur cacing berkembang menjadi larva di tanah kemudian masuk dalam tubuh satwa melalui penelanan (ingesti) bersama dengan makanan yang dimakan (Mulyadi, 2017). Faktor faktor yang mempengaruhinya adalah pakan, sistem pemeliharaan, musim dan kebersihan kandang. Rute penularan infeksi cacing adalah melalui mulut dari pakan rusa yang tercemar telur atau larva cacing (Handayani, 2015). 
Informasi telur cacing saluran pencernaan pada satwa liar yang di tangkarkan masyarakat Manokwari belum pernah dilakukan. Penelitian ini dilakukan untuk mengidentifikasi telur cacing pada saluran pencernaan satwa liar. Penelitian ini dapat digunakan sebagai informasi awal untuk infestasi parasit serta dapat menjadi acuan dalam pengendalian penyakit cacingan agar tidak merugikan kondisi satwa liar yang sudah ditangkarkan.

\section{MATERI DAN METODE}

Pengambilan sampel feses dilakukan dengan mengunjungi masyarakat yang memelihara satwa di Distrik Manokwari Timur dan Distrik Manokwari Barat. Penelitin dilaksanakan dari tanggal 10 Oktober sampai 30 November 2017.

\section{BAHAN DAN ALAT}

Sebanyak 10 ekor burung Nuri, 5 ekor Kakatua, 2 ekor burung Mambruk, 3 ekor burung Kasuari. Selain itu ada kelompok mamalia ada 5 ekor kangguru, dan 15 ekor rusa yang dipelihara oleh masyarakat di Manokwari. Analisa sampel feses yang dikumpulkan dari lapangan, dilakukan pemeriksaan di laboratorium Kesehatan Hewan Fakultas Peternakan Universitas Papua. Bahan kimia yang digunakan untuk analisa adalah metilen blue, garam jenuh. Peralatan-peralatan yang digunakan untuk analisa adalah tabung reaksi, objek gelas, dan mikroskop.

\section{CARA KERJA}

Penelitian ini dilakukan dengan metode observasi langsung dengan mengoleksi sampel feses pada satwa barung yang di kandangkan dan sampel feses bercampur tanah yang berada di dalam kandang untuk satwa mamalia. Sampel feses yang diambil adalah feses yang segar kemudian sampel feses dimasukkan ke dalam botol yang telah diberi larutan formalin $10 \%$, kemudian botol tersebut diberi label satwa burung maupun satwa mamalia. Sampel yang diambil selanjutnya dibawa ke Laboratorium Kesehatan Hewan, Fakultas Peternakan UNIPA.

Pemeriksaan dilakukan secara kualitatif dan kuantitatif. Pemeriksaan kualitatif dilakukan dengan metode natif dan metode kantitatif dilakukan dengan dua metoda yaitu flotasi dan sedimentasi. Metode natif dilakukan dengan mengambil feses sebanyak 3 gram, kemudian feses diencerkan dengan $100 \mathrm{ml}$ aquades dan dihomogenkan, kemudian teteskan pada kaca objek, tutup dengan kaca penutup dan periksa di bawah mikroskop dengan perbesaran 10 sampai 100 kali (Dirjen Peternakan, 1999).

Metode flotasi digunakan untuk jenis telur cacing parasit yang dapat mengapung dengan menggunakan larutan garam jenuh. Sampel feses satwa ditimbang sebanyak 3 gram dan dimasukkan dalam tabung. Kemudian tabung tersebut diisi $5 \mathrm{ml}$ larutan garam jenuh, dihomogenkan dan diisi kembali dengan larutan garam jenuh hingga cembung, didiamkan selama 45 menit. Selanjutnya pada mulut tabung ditutup dengan kaca penutup diangkat lalu diletakkan di atas objek gelas dan diamati di bawah mikroskop (Shaikenov et al., 2004).

Metode sedimentasi digunakan untuk jenis telur cacing parasit yang mengendap bersama feses satwa diambil sebanyak 3 g dimasukkan dalam tabung reaksi diisi akuades $30 \mathrm{ml}$ diaduk sampai homogen. Filtrat disaring sebanyak dua kali menggunakan kain kasa dan kapas ke dalam tabung sentrifus. Filtrat disentrifus selama tiga menit dengan kecepatan 3000rpm kemudian supernatan yang terbentuk dibuang perlahan sehingga menyisakan endapan. Endapan diberi metilen blue dan ditetaskan pada obyek gelas dan ditutup dengan cover gelas lalu endapan diamati di bawah mikroskop (Mohr, 1957). Identifikasi telur cacing dilakukan sesuai urutan taksonominya, kemudian dikelompokkan berdasarkan ordo, famili dan genus. Telur cacing yang telah difoto, diamati dengan mikroskop selanjutnya diidentifikasi untuk mengetahui jenisnya. Telur cacing nematode berisi sel telur (ovum) yang mukin tidak atau belum mengalami segmentasi (unsegmented). Unsur seluler yang tampak jelas pada telur trematoda ialah sel-sel kuning telur, sedang sel germinal tampak sebagai bagian transparan didaerah sekitar salah satu kutubnya. Kebanyakan telur trematoda mempunyai operculum pada salah satu kutubnya. Telur cacing cestoda memiliki bentuk spesifik misal segitiga, dan juga ada yang memiliki kapsul. Telur cacing yang 
ditemukan diidentifikasi menggunakan beberapa buku referensi yaitu Mohr (1957), Brown (1979), Margono (1996), Purnomo, Gunawan, Magdalena, Ayda dan Hijriani (1996), Gandahusada et al. (1998).

\section{HASIL DAN PEMBAHASAN}

Hasil pengamatan terhadap sampel feses satwa yang dipelihara menunjukkan bahwa sampel feses satwa burung, yaitu Nuri (10 ekor), Kakatua (5 ekor), Mambruk (2 ekor) dan Kasuari (3 ekor) tidak ditemukan telur cacing, sedang hasil analisa feses satwa mamalia ditemukan jenis telur cacing Nematoda pada 15 ekor rusa dan jenis telur cacing Cestoda pada 5 ekor kangguru pohon. Identifikasi terhadap temuan berdasarkan Mohr (1957) menunjukan bahwa jenis telur cacing tersebut_adalah Ascaris sp (berembrio), Strongyl sp pada rusa (Cervus timorensis) dan Taenia sp pada kangguru pohon (Macropus agilis) (Tabel 1).

Tabel 1. Identifikasi telur cacing pada saluran pencernaan satwa liar

\begin{tabular}{|c|c|c|c|c|c|c|c|}
\hline \multirow{2}{*}{ Satwa } & \multirow{2}{*}{$\begin{array}{l}\text { Jumlah } \\
\text { sampel }\end{array}$} & \multicolumn{3}{|c|}{ Metode } & \multirow{2}{*}{$\begin{array}{l}\text { Telur } \\
\text { cacing }\end{array}$} & \multirow{2}{*}{$\begin{array}{c}\text { Jumlah } \\
\text { telur cacing }\end{array}$} & \multirow{2}{*}{ Keterangan } \\
\hline & & Natif & Flotasi & Sedimen & & & \\
\hline Nuri & 10 & negatif & negatif & negatif & - & 0 & $\begin{array}{l}\text { Tidak ditemukan telur } \\
\text { cacing }\end{array}$ \\
\hline Kakatua & 5 & negatif & negatif & negatif & - & 0 & $\begin{array}{l}\text { Tidak ditemukan telur } \\
\text { cacing }\end{array}$ \\
\hline Mambruk & 2 & negatif & negatif & negatif & - & 0 & $\begin{array}{c}\text { Tidak ditemukan telur } \\
\text { cacing }\end{array}$ \\
\hline Kasuari & 2 & negatif & negatif & negatif & - & 0 & $\begin{array}{l}\text { Tidak ditemukan telur } \\
\text { cacing }\end{array}$ \\
\hline Kangguru & 5 & negatif & negatif & positif & Taenia sp & 8 & Sedimen \\
\hline \multirow[t]{2}{*}{ Rusa Timor } & 15 & positif & positif & positif & Stronglye sp & 10 & $\begin{array}{l}\text { Natif 3, Flotasi 3, } \\
\text { Sedimen } 4\end{array}$ \\
\hline & & & & & Ascaris $\mathrm{sp}$ & 3 & $\begin{array}{l}\text { Natif } 1 \text {, Flotasi } 1, \\
\text { Sedimen } 1\end{array}$ \\
\hline
\end{tabular}

Sistem pemeliharaan dari masing-masing satwa dapat dilihat pada Tabel 2. Hasil ini memberikan gambaran tentang infestasi parasit dan juga indikasi kurangnya perhatian pemelihara tehadap kondisi kesehatan satwa peliharaan. Sementara itu minat memelihara satwa liar sebagai hewan kesayangan cenderung meningkat dari waktu ke waktu.
Penelitian seperti ini baru pertama kali dilakukan di Manokwari dan sekitarnya. Oleh karena itu literatur pembanding dari penelitian sebelumnya yang dilakukan di Manokwari tidak ditemukan, sehingga diharapkan hasil penelitian ini menjadi acuan bagi penelitian yang sama di waktu mendatang.

Tabel 2. Jenis telur cacing, parasit dan sistem pemeliharaan

\begin{tabular}{|c|c|c|c|c|}
\hline $\begin{array}{l}\text { Kelompok } \\
\text { Satwa }\end{array}$ & Jenis Satwa / Jumlah & Jenis Telur cacing & Jenis Parasit & Lokasi pemeliharaan \\
\hline \multirow[t]{4}{*}{ Burung } & Nuri (Lorius lory) $(\mathrm{N}=10)$ & Tidak ditemukan & & Rumah (dikandangkan) \\
\hline & $\begin{array}{l}\text { Kakatua (Cacatua } \\
\text { sulphurea) }(\mathrm{N}=5)\end{array}$ & Tidak ditemukan & & Rumah (dikandangkan) \\
\hline & $\begin{array}{l}\text { Mambruk victori (Goura } \\
\text { victoria) }(\mathrm{N}=2)\end{array}$ & Tidak ditemukan & & Rumah (dikandangkan) \\
\hline & $\begin{array}{l}\text { Kasuari gelambir ganda } \\
\text { (Casuarius casuarius) }(\mathrm{N}=3)\end{array}$ & Tidak ditemukan & & $\begin{array}{l}\text { Rumah (diumbar di } \\
\text { halaman) }\end{array}$ \\
\hline \multirow[t]{2}{*}{ Mamalia } & $\begin{array}{l}\text { Kanguru pohon (Macropus } \\
\text { agilis) }(\mathrm{N}=5)\end{array}$ & Cestoda & Taenia sp. & $\begin{array}{l}\text { Rumah (diumbar di } \\
\text { halaman) }\end{array}$ \\
\hline & $\begin{array}{l}\text { Rusa Timor (Cervus } \\
\text { timorensis) }(\mathrm{N}=15)\end{array}$ & Nematoda & $\begin{array}{l}\text { Ascaris } \mathrm{sp} . \\
\text { Strongyle } \mathrm{sp}\end{array}$ & $\begin{array}{l}\text { Rumah (diumbar di } \\
\text { halaman) }\end{array}$ \\
\hline
\end{tabular}

Tidak ditemukannya telur cacing pada sampel feses burung kemungkinan karena burung dipelihara di dalam sangkar atau kandang yang digantung sehingga mengurangi 
kontak langsung hewan peliharaan dengan permukaan tanah. Selain itu sanitasi kandang selalu terjaga, tempat pakan dan minum dibersihkan secara berkala. Berbeda dengan rusa dan dan kangguru pohon yang diumbar di sekitar halaman rumah, selalu bersentuhan langsung dengan tanah. Kondisi ini memungkinkan hewan peliharaan untuk terinfeksi penyakit, terlebih mereka mengkonsumsi pakan langsung dari tanah dan tempat minum mereka jarang dibersihkan. Achmad et al. (2010) menyatakan bahwa sistem pemeliharaan dan sanitasi kandang sangat berpengaruh terhadap status kesehatan hewan. Penyakit parasitik biasanya tidak mengakibatkan kematian hewan ternak, namun menyebabkan kerugian berupa penurunan kondisi badan dan daya produktivitas hewan (Arifin, 1982).

Hasil kajian Mustika (2004) ternyata bahwa telur cacing dijumpai pada ruminansia di negara beriklim tropis dengan kondisi lingkungan yang lembab. Berdasarkan hasil uji laboratorium ternyata bahwa telur cacing Taenia sp sebanyak 8, telur cacing Strongyle sebanyak 10 dan telur cacing Ascaris sp sebanyak 3. Jenis cacing yang pertama yaitu Taenia sp. Umumnya telur cacing ini terdapat pada ternak babi. Pengamatan di penangkaran, menunjukan bahwa kondisi tanah yang lembab merupakan tempat yang cocok bagi pertumbuhan telur cacing Taenia sp, sama dengan kajian yang dilakukan oleh (Trikanti, 2013). Kemungkinan ditemukannya telur cacing Taenia sp diduga karena pemilik mengumbar kanggurunya di halaman rumah sedangkan di halaman rumah tersebut terdapat babi yang diliarkan oleh masyarakat. Hal inilah yang diduga menjadi penyebab kangguru terinfestasi telur cacing melalui dedaunan yang dimakan. Siklus hidup cestoda tidak langsung, yaitu dengan telur yang ditumpahkan oleh tungau sebagai vektor. Larva (cysticercoid) menetas dalam hospes perantara dan menembus rongga tubuh, dimana ia menunggu asupan dari tungau oleh hospes definitif. Satwa mamalia mencerna tungau ini bersama-sama dengan daun-daunan yang dikonsumsi dan cysticercoid dilepaskan, kemudian berkembang menjadi tahap dewasa untuk memproduksi telur baru (Kaufmann, 1996). Ternak akan terinfeksi jika menelan cysticercoid yang menginfeksi tungau yang ada pada biji-bijian (Hendrix dan Robinson, 2006).

Infeksi oleh cestoda bersifat zoonosis (dapat menulari manusia). Cestoda memerlukan dua inang perantara. Cacing cestoda akan berkembang biak sebelum menginfeksi di usus, kemudian membentuk larva Metacestoda dalam organ internal hewan dan masuk ke tubuh manusia yang mengkonsumsi daging (Tarmudji, 2006). Telur cacing Taenia sp merupakan cestoda yang siklus hidupnya membutuhkan lebih dari satu inang dan telur diproduksi dalam jumlah banyak. Kangguru sebagai hospes defenitif diduga terinfeksi Taenia sp karena mengkonsumsi pakan yang sudah terkontaminasi larva. Cacing dewasa mempunyai scolex dan menyerang usus diikuti oleh cacing muda dan proglotid (Levinne, 1994).

Jenis telur cacing ke dua yaitu telur cacing Strongyle sp. lebih banyak ditemukan pada pemeriksaan sampel feses. Zalizar (2017), menjelaskan bahwa siklus hidup cacing dari anggota Strongyle sp. secara langsung dan tanpa inang, sehingga cacing dapat dengan mudah menyebar. Pada penangkaran tidak di sediakan tempat makan yang terpisah dengan aktivitas lainnya sehingga terjadi infestasi telur cacing pada rusa yang lain. Hal ini juga yang menjadi pemicu feses yang terinfestasi telur cacing dengan mudah tercampur dengan makanan dan akhirnya tertelan. Jenis telur cacing ketiga yaitu Ascaris sp. Siklus hidup nematoda bersifat langsung, dengan cara seksual di dalam hospes. Cacing betina dewasa dalam hospes menghasilkan telur, yang dikeluarkan ke lingkungan bersama feses. Siklus hidup Nematoda umumnya melalui empat stadium larva (L1 - L4) dengan L3 yang menjadi stadium larva infektif bagi hospes baru. Larva spesies Nematoda kebanyakan bersifat pasif pada waktu diambil oleh hospes selama merumput. L3 yang tertelan ketika hospes merumput, selanjutnya mengalami pelepasan kutikula di dalam abomasum. Pada beberapa parasit, stadium L3 bisa masuk ke hospes baru dengan penetrasi aktif melalui kulit, kemudian masuk melalui sistem sirkulasi darah dan limpatik atas, paru-paru dan trakea 
masuk ke dalam oesophagus dan saluran gastrointestinal (Kaufmann, 1996).

Dalam penangkaran satwa mamalia terdapat ayam dan babi milik warga yang masuk dalam penangkaran, disamping itu juga ditemukannya cangkang siput dan juga di sekitar penangkaran masih ditemukan kotoran manusia. Hal ini menyebabkan pada saat pengambilan feses besar kemungkinan pada tanah terdapat jenis telur cacing nematode yang mencemari feses kangguru dan rusa. Pengambilan sampel pada penelitian ini dilakukan pada saat musim panas dan hujan sedangkan pengambilan sampel pada penelitian (Basrul, 2015) dilakukan pada saat musim hujan saja. Musim hujan diduga menjadi penyebab infestasi cacing saluran pencernaan karena keadaan lingkungan yang semakin lembab sehingga menunjang perkembangan cacing saluran pencernan. Menurut Widjajanti (2004), musim hujan menyebabkan kelembaban udara yang tinggi, dan temperatur yang rendah sehingga kondisi ini disukai oleh parasit cacing untuk berkembang. Sedangkan Hambal (2013), menjelaskan bawha pengaruh umur erat kaitannya dengan kurun waktu infestasi terutama di lapangan. Makin tua umur ternak makin tinggi prevalensi intensitas. Pada ternak muda, prevalensinya lebih rendah. Hal ini disebabkan intensitas makan rumput ternak muda masih rendah dibandingkan ternak dewasa, ini karena ternak muda masih minum air susu induknya, sehingga kemungkinan untuk terinfekasi larva metaserkaria lebih kecil. Musim kemarau berkaitan terhadap tingkat kejadian cacing yang ditemukan pada feses. Hal tersebut disebabkan karena kondisi tanah dan atmosfer pada musim kemarau cukup panas, sehingga feses cepat mengering dan menyebabkan telur cacing menjadi rusak dan mati (Muthiadin, 2018). Tingkat prevalensi cacing pada rusa timor berbeda di setiap wilayah. Hal tersebut terjadi karena adanya perbedaan geografis dan kondisi lingkungan yang mempengeruhi keberadaan siput sebagai perantara larva cacing. Lebih lanjut, Rozi (2015) menjelaskan bahwa siput yang membawa larva cacing memungkinkan terjadinya pencemaran pakan rusa. Faktor lainnya dapat dipengaruhi oleh manajemen pemeliharaan, umur, kualitas kandang, dan sanitasi lingkungan (Garsetiasih, 2007).

\section{KESIMPULAN}

Semua spesies burung yang dipelihara di Manokwari belum terinfestasi telur cacing saluran pencernaan, terbukti dengan tidak ditemukannya telur cacing pada sampel feses. Jika dikaitakan dengan sistem pemeliharaan, semua burung dikandangkan sehingga kemungkinan terinfestasi parasit secara langsung sangat kecil. Sampel feses mamalia yang dipelihara terinfestasi telur cacing saluran pencernaan terbukti dengan ditemukannya telur cacing pada sampel feses. Identifikasi telur cacing yang ditemukan pada sampel feses satwa mamalia Taenia sp dari kelas Cestoda pada kangguru dan Strongyle sp dan Ascaris sp (berembrio) dari kelas Nematoda pada rusa. Sistem pemeliharaan dengan cara diumbar di halaman memberikan peluang jenis hewan peliharaan terinfestasi parasit saluran pencernaann. Tingkat infestasi telur cacing parasit pada satwa yang dipelihara oleh masyarakat di Manokwari masih tergolong rendah.

\section{UCAPAN TERIMAKASIH}

Ucapan terima kasih disampaikan kepada mahasiswa D3 Keswan yang membantu pengambilan data sebagai bagian dari praktikum Mata Kuliah Manajemen Kesehatan Satwa Liar. Penghargaan dan ucepan terima kasih layak disampaikan kepada responden pemeliharan satwa yang mengijinkan pengambilan sampel feses dari hewan peliharaan mereka.

\section{DAFTAR PUSTAKA}

Achmad A dan Nurdin D. 2010. Potensi dan Kebijakan Pengelolaan Satwa Liar di Hutan Pendidikan Unhas. Prosiding hasil Litbang Mendukung Rehabilitasi dan Konservasi Hutan untuk Kesejahteraan Masyarakat. Bogor. Pusat Penelitian dan Pengembangan Konservasi dan Rehabilitasi.

Andriansyah, Candra D, Agil M, Handayani SU dan Tiuria R. 2008. Diseases Surveillance around Way Kambas National Park to support Sumatran rhino conservation and health. Proceedings of Asian Zoo Wildlife Medicine and Conservation, Bogor, Indonesia 19-22 August 2008. p. 128-129 
Arifin C. dan Soedarmono. 1982. Parasit Ternak dan Cara Penanggulagannya. Penerbit Kanisius. Yogyakarta

Basrul J. 2015.Identifikasi Endoparasit Pada Saluran Pencernaan Rusa Tutul (AxisAxis) Di Taman Pintu Satu Universitas Hasanuddin Makassar. [Skipsi]. Makassar. Universitas Hasanuddin.

Brown HW. 1979. Dasar Parasitologi Klinis. P.T Gramedia. Jakarta: xiv+535 Hlm.

Dirjen Peternakan. 1999. Manual Standar Metode Diagnosa Laboratorium Kesehatan Hewan Edisi I. Direktorat Bina Produksi Kesehatan Hewan. Departemen Pertanian. Jakarta.

Rozi F, Handoko J dan Febriyanti R. 2015. Infestasi Cacing Hati (Fasciola sp.) dan Cacing Lambung (Paramphistomum sp.) pada Sapi Bali Dewasa di Kecamatan Tenayan Raya Kota Pekanbaru. JSV. Vol 33 No. 1:8-15. 2015.

Larasati $H$, Hartono $M$ dan Siswanto, "Prevalensi Cacing Saluran Pencernaan Sapi Perah Periode Juni-juli 2016 Pada Perusaan Rakyat di Provinsi Lampung", Jurnal Penelitian Perusaan Indonesia. Vol 1 No. 1: 8 - 15. 2016.

Hambal M, Arman S dan Agus D. 2013. Tingkat Kerentanan Fasciola gigantica Pada Sapi Dan Kerbau Di Kecamatan Lhoong Kabupaten Aceh Besar. Jurnal Medika Veterinaria. Fakultas Kedokteran Hewan Universitas Syiah Kuala, Banda Aceh. Vol 7 [1].

Hendrix CM and Robinson E. 2006. Diagnoctic Parasitology for Veterinary Technicians. Third Edition. Mosby Elsevier Inc. St. Louis, Missouri.

Koibur J, Lalenoh DM dan Pattiselanno F. 2017. Memelihara paruh bengkok sebagai hewan kesenangan di Manokwari. Konferensi Peneliti dan Pengamat Burung Indonesia 3. Universitas Udayana, Bali.

Zalizar L. 2017. Helminthiasis Saluran Cerna Pada Sapi Perah, Jurnal Ilmu-Ilmu Peternakan. Vol 27 No. 7:1-7

Levine G. 1994. Veterinary Parasitology. Edisi ke-3 Colage of Veterinery Medicine. University of Illinois. Urbana. Illonois.

Indradji M, Yuwono E, Indrasanti D, Samsi M, Sufiriyanto AR, Herlan B dan Herdiana,
Studi Kasus Tingkat Infeksi Cacing Pada Perusaan Kambing Boer di Kabupaten Banyumas. Jurnal Ilmiah Perusaan Terpadu. Vol 6 No. 1: 93-96. 2018.

Margono SS. 1996. Pemeriksaan tanah, debu, usap jari dan kotoran kuku terhadap telur A. Lubricoides. Majalah Kedokteran Indonesia. Vol 46, No 11. Hal 621-626.

Mohr JC. 1957. Parasit-Parasit Hewani Jang Utama Pada Manusia. Bagian I. Protozoa danVermes. Fakultas Kedokteran Negeri Medan.

Muryani A, Tiuria R, Andriansyah dan Agil M. 2008. Helminthes parasite at feces of Sumatran rhinoceros (Dicerorhinus sumatrensis) dan Sumatran Elephant (Elephas maximus sumatranus) in Way Kambas National Park Lampung (semi insitu). Proceedings of Asian Zoo Wildlife Medicine and Conservation, Bogor, Indonesia 19-22 August 2008. p142

Mustika I dan Riza ZA. 2004. Peluang pemanfaatan jamur nematofagus untuk mengendalikan nematoda parasit pada tanaman dan rusa. Jurnal Litbang Pertanian. Vol 23 No. 4:115-122.

Muthiadin C, Aziz IR dan Fitriyana. 2018. Identifikasi dan Prevalensi Telur Cacing Parasit Pada Feses Sapi (Bos, sp) Yang Digembalakan di Tempat Pembuangan Akhir Sampah (TPAS) Tamangapa Makassar. Biotropic the Journal of Tropical Biology. Vol 2 No. 1:17-23.

Trikanti N. 2013. Hubungan Pengetahuan Tentang Kecacingan dan Jenjang Kelas Dengan Kejadian Kecacingan Soil Transmitted Helminth (STH) Pada Siswa Kelas 4, 5 dan 6 SD Negeri 1 Pinang Jaya. Skripsi. Fakultas Pertanian. Universitas Lampung. Bandar Lampung.

Handayani P, Santosa PE dan Siswanto. 2015. Tingkat Infestasi Cacing Saluran Pencernaan pada Sapi Bali di Kecamatan Sukoharjo Kabupaten Pringsewu Provinsi Lampung. Jurnal Ilmiah Perusahaan Terpadu. Vol 3 No. 3: 127-133.

Pattiselanno F. 2003. The wildlife value: Example from West Papua, Indonesia. Tigerpaper 30 (1): 27-29

Pattiselanno F. 2006. The wildlife hunting in Papua. Biota 11(1): 59-61 
Pattiselanno F, Isir D, Takege A dan Seseray D. 2008. Kajian awal penangkaran rusa (Cervus timorensis) sistem back yard di Manokwari. Biosfera 25(2): 95-100

Purnomo, Magdalena, Ayda dan Harijani. 1996. Atlas Helminthologi Kedokteran. PT. Gramedia. Jakarta

Purwaningsih, Noviyanti, Widayati I, Nurhayati D and Baaka A. 2016. Differences in The Rearing System toward Bali Cattle Gastrointestinal Helminths Infestation in Prafi District, Manokwari Regency, West Papua Province. 1st International Conference on Tropical Agriculture (ICTA). October 25-26, 2016. Yogyakarta.

Garsetiasih R, Heriyanto dan Atmaja J. 2007. Pemanfaatan Dedak Sebagai Pakan Tambahan Rusa. Buletin Plasma Nutfah. Vol 9 No. 2: 23-27.

Hasan S. 2012. Hijauan Pakan Tropik. IPB Press. Hal: 112. Bogor.
Shaikenov BT. 2004. Short Report the Use Of Polymerase Chain Reaction to Detect Echinococcus granulosus (GI Strain) Eggs in Soil Samples. AM.J.Tropic.

Mulyadi T, Siswanto dan Hartono M. 2017. Prevalensi Cacing Saluran Pencernaan Pada Kambing Peranakan Etawa (PE) di Kelompok Tani Kecamatan Gedong Tataan Kabupaten Pesawaran Lampung. Jurnal Riset dan Inovasi Perusaan. Vol 2 No. 2:21-26.

Pratiwi U. 2010. Infestasi Cacing Parasitik pada Harimau (Panthera tigris) di Taman Rekreasi Margasatwa Serulingmas, Kebun Binatang Bandung dan Taman Safari Indonesia. Skripsi. Institut Pertanian Bogor. Bogor. 2010.

Widjajanti S. 2004. Fasciolosis pada manusia: mungkinkah terjadi di Indonesia. Buletin Ilmu Peternakan Indonesia, 14(2): 65-72 